\title{
Interactions between bees and Ludwigia elegans (Camb.) Hara (Onagraceae) flowers at different altitudes in São Paulo, Brazil
}

Miriam Gimenes ${ }^{1}$

\begin{abstract}
Populations of Ludwigia elegans (Camb.) Hara were examined in Aluminio $(600 \mathrm{~m})$ and Campos do Jordão $(1520 \mathrm{~m})$, in the State of São Paulo. Flowers of both populations are self-incompatible and dependent on bees for pollination. Flowers of Ludwigia elegans at the Aluminio site were visited by about 30 different species of bees, and those at Campos do Jordão by 10. These results can be related to climatic differences at the two sites, especially temperature, due to their difference in altitude. In spite of the difference in the absolute number of bee species seen at each site, Tetraglossula anthracina (Michener, 1989) (Colletidae) can be considered a specialized and efficient pollinator in both areas, since it visited these flowers frequently and showed many morphological and behavioral adaptations for pollen and nectar collection.
\end{abstract}

KEY WORDS. Apoidea, Ludwigia elegans, Tetraglossula, Rhophitulus, Pseudagapostemon

Ludwigia is the largest and most diversified genera in the family Onagraceae. All 82 species in this genus are mesophytic, growing in wet areas in tropical and subtropical regions (HASSE 1990; BRACK 1985). Forty-five species occur in South America (RAMAMOORTHY \& ZARDINI 1987). JACOBS et al. (1994) observed that Ludwigia peruviana (L.) Hara, originally from the Americas, was introduced in the wet areas around Sydney, Australia and in a short period of time became the dominant species, out competing many native species. Ludwigia elegans is one of the most common species of this genus in Brazil, being abundant in humid areas in the States of Bahia, Minas Gerais, Goiás, Mato Grosso, Rio de Janeiro, São Paulo, Paraná, Santa Catarina and Rio Grande do Sul (RAMAMOORTHY \& ZARDINI 1987).

Studies of the interactions between Ludwigia flowers and their visitors are quite interesting and involve several important morphologic features found in Onagraceae. The flowers usually produce large pollen grains (approximately 100 $\mathrm{um}$ in diameter) which are interconnected by viscin threads and form a clinging mass (HESSE 1984). As a result, many pollen grains are transferred simultaneously and pollination efficacy is increased (CRUDEN 1981). Most bees, however, have difficulty collecting this type of pollen. Species that successfully harvest this pollen usually have specialized bristles on the scopa that are long, stiff, and slightly branched (ROBERTS \& VALESPIR 1978; GIMENES 1991). In addition to these structural adaptations, specialist bees which visit Onagraceae flowers can exhibit

1) Departamento de Ciências Biológicas, Universidade Estadual de Feira de Santana. Rodovia BR 116, Km 3, 44031-460 Feira de Santana, Bahia, Brasil. E-mail: mgimenes@uefs.br 
certain behavioral characteristics, such as rapid body and leg movements, that enhance pollen harvesting efficiency (MACSWAIN et al. 1973; GIMENES 1997). Additionally, GIMENES et al. $(1993,1996)$ observed a circadian synchrony between Ludwigia elegans flowers and the visiting specialist bees.

There are a number of studies on pollinators of Ludwigia flowers in South America. SAZIMA \& SANTOS (1982) showed that Tetrapedia sp. was an effective pollinator of Ludwigia sericea (Camb.) Hara, whereas Ptilothrix relata Holmberg, 1903 (Anthophoridae) as well as other less abundant bees, were only occasional pollinators. Pseudagapostemon sp. and Augochlora sp. (Halictidae) were considered pollen thieves. MARTINS \& ANTONINI (1994), observed that Diadasina distincta (Holmberg, 1903) (Anthophoridae) was an oligolectic visitor of Ludwigia suffruticosa (L.) Gomez flowers. GIMENES (1997), studying the pollination of $L$. elegans in Ribeirão Preto, State of São Paulo, observed that Tetraglossula bigamica (Strand, 1910) (Colletidae) was an effective pollinator, while Pseudagapostemon brasiliensis Cure, 1989, a very frequent visitor, was only a fortuitous pollinator.

The objective of this work was to identify the bee species that visit $L$. elegans flowers in two areas with different altitudes, Aluminio and Campos do Jordão, and to analyze their harvesting and pollination efficiency in terms of the local ecology and their behavioral.

\section{MATERIAL AND METHODS}

Observations of $L$. elegans flowers were undertaken in populations located in areas near the cities of Aluminio and Campos do Jordão, São Paulo, Brazil.

At Aluminio, fieldwork was done at Fazenda Gir (altitude $600-832 \mathrm{~m}$, $\left.23^{\circ} 52^{\prime} \mathrm{S} x 47^{\circ} 02^{\prime} \mathrm{W}\right)$. In Campos do Jordão, observations were made in the Campos do Jordão State Park (altitude $1,520 \mathrm{~m}, 22^{\circ} 45^{\prime} \mathrm{S}$ x $45^{\circ} 30^{\prime} \mathrm{W}$ ) which is still largely dominated by original Araucaria and Podocarpus forests (SEIBERT 1975).

Data concerning monthly mean temperatures, relative humidity, and total monthly rainfall in each area was provided by the Centro de Meteorologia e Climatologia de São Paulo. Additionally, temperature and relative humidity were measured at each site during every observation session.

During the study, the average temperature varied between 16 and $24^{\circ} \mathrm{C}$ in Aluminio, and between 10 and $18^{\circ} \mathrm{C}$ in Campos do Jordão. The relative humidity varied from 68 to $78 \%$ in Aluminio, and from 82 to $88 \%$ in Campos do Jordão. The period of greatest rainfall occurred between October and January at the Aluminio site, and between October and March in Campos do Jordão.

The two study sites were visited alternately every month between November 1989 and October 1991. Time of flower opening, the species of visiting bees, and behavioral characteristics of the visit (pollen or nectar harvest) were monitored visually during three consecutive days at each individual site each month.

At the beginning of each day of observation, all blossoming specimens of $L$. elegans encountered in the area were counted. One plant was then chosen at random for the phenological studies, and the number of flowers on this plant was noted. Observations of visitors were conducted on approximately 10 flowers of this plant 
during 15-minute periods each hour, from 7:00 a.m. to 6:00 p.m., for three consecutive days. Total body length (between median ocellus and apex of the abdomen) of the most frequent bees was measured. One to three specimens of each bee species were collected for identification and for morphological studies.

To examine the reproductive biology of $L$. elegans, buds were bagged one day before anthesis. Seed production was determined in 89 fruits ( 49 from Aluminio and 40 from Campos do Jordão) from plants which had experienced spontaneous autopollination (autogamy), induced autopollination (autogamy), cross pollination (xenogamy or geitonogamy) in emasculated flowers, and apomixy.

Specimens of $L$. elegans were deposited at the UEC Herbarium - Universidade Estadual de Campinas. Dr. Elza M. Zardini of Missouri Botanical Garden identified $L$. elegans material. Specimens of visitant bees were deposited at the Museu de Zoologia, São Paulo, Brazil. Most of the bees were identified by J.S. Moure. D.A.Yanega identified Pseudagapostemon brasiliensis, P. pruinosus Moure \& Sakagami, 1984 and Nomada sp. Rhophitulus sp. was identified by L. Ruz, and Tetraglossula anthracina by G.A.R. de Melo (identified previously as Heterosarelus and Tetraglossula ventralis, respectively, in GIMENES et al. (1996)).

\section{RESULTS}

Ludwigia elegans blossomed throughout the year in Aluminio, and from December to June in Campos do Jordão. In both areas, flowers opened in the early morning and would lose their petals and their anthers by the end of the afternoon.

The populations of L. elegans flowers at both the Aluminio and Campos do Jordão sites were self-incompatible. Apomixy was not observed in either area. The results of the pollination experiments (spontaneous, induced autopollination, crossed pollination and emasculated flowers) are presented in table I.

Table I. Reproductive biology of Ludwigia elegans. Seed production was determined from plants in Aluminio (AL) and Campos do Jordão (CJ). It were carried out experiments on spontaneous autopollination (autogamy), induced autopollination (autogamy), cross pollination (xenogamy or geitonogamy) in emasculated flowers, and apomixy.

\begin{tabular}{|c|c|c|c|c|c|c|}
\hline \multirow{2}{*}{ Experiments } & \multicolumn{2}{|c|}{ Flowers (n) } & \multicolumn{2}{|c|}{ Fruits (n) } & \multicolumn{2}{|c|}{ Success (\%) } \\
\hline & $A L$ & CJ & $\mathrm{AL}$ & CJ & AL & CJ \\
\hline Spontaneous autopollination & 10 & 10 & 0 & 0 & 0 & 0 \\
\hline Induced autopollination & 16 & 11 & 0 & 0 & 0 & 0 \\
\hline Xenogamy & 8 & 6 & 6 & 7 & 87 & 100 \\
\hline Geitonogamy & 11 & 11 & 5 & 1 & 45 & 9 \\
\hline Apomixy & 4 & 2 & 0 & 0 & 0 & 0 \\
\hline
\end{tabular}

The flowers of $L$. elegans were visited predominantly by bees. About 30 species of visitant bees were observed at the Aluminio site, and 10 at Campos do Jordão. Eight species of bees were common to both areas (Tab. II). Most of the visitant bees collected mainly nectar, although a few of them were efficient pollen harvesters. 
Table II. List of bees visiting Ludwigia elegans flowers at the Aluminio (AL) and Campos do Jordão (CJ) study sites, from November 1989 to October 1991. ( $\left.{ }^{\star}\right)$ Very frequent visitant species.

\begin{tabular}{|c|c|c|}
\hline Species & Campos do Jordão & Aluminio \\
\hline \multicolumn{3}{|l|}{ Andrenidae } \\
\hline Cephalurgus anomalus Moure \& Oliveira, 1962 & - & $x$ \\
\hline Rhophitulus sp. & $x^{*}$ & $x^{*}$ \\
\hline Psaenythia chrysorrhoea Gerst & $x$ & - \\
\hline Colletidae & & $\mathrm{x}$ \\
\hline Tetraglossula bigamica (Strand, 1910) & - & $x^{*}$ \\
\hline Tetraglossula anthracina (Michener, 1989) & $x^{*}$ & $x$ \\
\hline \multicolumn{3}{|l|}{ Halictidae } \\
\hline Augochlora amphitrite (Schrottky, 1909) & $\mathrm{x}$ & $\mathrm{x}$ \\
\hline Augochlora sp. & $x$ & - \\
\hline Dialictus sp. & $x$ & $x$ \\
\hline Pseudagapostemon brasiliensis Cure, 1989 & - & $x^{*}$ \\
\hline Pseudagapostemon pruinosus Moure \& Sakagami, 1984 & - & $x^{*}$ \\
\hline Pseudagapostemon sp. & - & $x^{*}$ \\
\hline \multicolumn{3}{|l|}{ Megachilidae } \\
\hline Megachile (Chrysosarus) pseudanthidioides Moure 1945 & - & $x$ \\
\hline Megachile spp. & - & $x$ \\
\hline Coelioxys sp. & - & $x$ \\
\hline Hypanthidium sp. & - & $x$ \\
\hline \multicolumn{3}{|l|}{ Anthophoridae } \\
\hline Ceratina sp. & - & $x$ \\
\hline Ceratina (Crewella) sp. & $\mathrm{x}$ & $\mathrm{x}$ \\
\hline Ceratina (Crewella) maculifrons (Smith, 1854) & - & $x$ \\
\hline Diadasina riparia Ducke, 1907 & - & $x$ \\
\hline Exomalopsis spp. & - & $x$ \\
\hline Exomalopsis fulvofasciata Smith, 1879 & - & $x$ \\
\hline Melissoptila (Thyreothremma) sp. & - & $\mathrm{x}$ \\
\hline Melissoptila sp. & $x^{*}$ & $x^{*}$ \\
\hline Nomada sp. & - & $x$ \\
\hline Ptilothrix relata Hoimberg, 1903 & - & $x$ \\
\hline Tetrapedia rugulosa Friese, 1899 & $x$ & $\hat{x}$ \\
\hline \multicolumn{3}{|l|}{ Apidae } \\
\hline Apis mellifera Linnaeus, 1758 & $x^{*}$ & $x^{*}$ \\
\hline Bombus (Fervidobombus) morio Swederus, 1787 & - & $x$ \\
\hline Paratrigona lineata (Lepeletier, 1836) & - & $x$ \\
\hline Trigona spinipes Fabricius, 1793 & - & $\mathrm{x}$ \\
\hline
\end{tabular}

Among the numerous bee species observed, Tetraglossula anthracina and Rhophitulus sp. (Andrenidae) were the most frequent visitors at both Aluminio and Campos do Jordão, while Pseudagapostemon brasiliensis, P. pruinosus and Pseudagapostemon sp. were very frequent only at Aluminio (Tab. III). These bees collected both pollen and nectar from L. elegans flowers.

At the Aluminio site, females and males of Pseudagapostemon spp. were also observed visiting flowers of Ludwigia sericea and Ludwigia longifolia (DC.) Hara that grew nearby.

Tetraglossula anthracina and Rhophitulus sp. visited flowers of L. elegans in both areas, principally between December and April. Species of Pseudagapostemon were active during the entire flowering period of L. elegans at Aluminio, although they were not observed at Campos do Jordão. As the different species of Pseudagapostemon are very similar, making it almost impossible to distinguish between them during their flower visits, the number of visits was calculated for the genera as a whole (Tab. III). 
Table III. Number of total visits observed to Ludwigia elegans flowers by the most frequent visitant species of bees s at the Aluminio (AL) and Campos do Jordão (CJ) study sites.

\begin{tabular}{lccc}
\hline & & \multicolumn{2}{c}{ Number of visits } \\
\cline { 3 - 4 } Species & Area & Females & Males \\
\cline { 3 - 4 } & & 422 & 19 \\
Tetraglossula anthracina & AL & 778 & 431 \\
Tetraglossula anthracina & CJ & 543 & 77 \\
Rhophitulus sp. & AL & 623 & 84 \\
Rhophitulus sp. & CJ & 508 & 398 \\
Pseudagapostemon spp. & AL & 7143 & - \\
Apis mellifera & AL & 2313 & - \\
Apis mellifera & CJ & 369 & - \\
Melissoptila spp. & AL & 561 & - \\
Melissoptila sp. & CJ & & \\
\hline
\end{tabular}

Apis mellifera Linnaeus, 1758 (Apidae), was a very frequent visitor, collecting nectar, and occasionally pollen. This species was present during the entire flowering season at the Aluminio site, but was only observed visiting L. elegans flowers at Campos do Jordão between February and April.

Various other bee species were also very frequent visitors of $L$. elegans flowers, in search of nectar rewards. At Aluminio, females of Melissoptila sp. and M. (Thyreotremma) sp. (Anthophoridae) visited these flowers from November to May, with a peak of activity in December and April. At the Campos do Jordão site, visitant females of Melissoptila sp. were observed from January to March, with a peak of activity during February.

\section{Morphologic adaptations}

Females of $T$. anthracina (length body $9.57 \mathrm{~mm}$ ) have scopa placed at the underside of abdominal segments III to VI. These are formed by stiff, unbranched and sparsely distributed bristles. The tibias of the posterior legs have hairs similar to those of the abdominal scopa. The disposition of the bristles on the abdominal scopa, as well as on the posterior tibias, permits only a weak attachment of the $L$. elegans pollen mass to the bee's body.

Rhophitulus sp. (length body $6.46 \mathrm{~mm}$ ) has scopa located on the tibias of its hind legs. These tibia hairs are stiff, sparse, unbranched bristles. Ludwigia pollen grains were observed attached to the scopa of the tibias of these bees as well as spread among the hairs on other parts of their bodies.

Females of Pseudagapostemon observed visiting $L$. elegans flowers were approximately the same size $(7.0 \mathrm{~mm})$ as Rhophitulus, and had similar scopa located mainly on the femurs of their hind legs. These hairs were long, slim, slightly branched, hooked and sparse where the pollen grains attached.

Females of Melissoptila sp. (body length $8.32 \mathrm{~mm}$ ) have scopa located on the hind tibias and basitarsus. These are short, stiff, dark bristles with grooves and sparse branches. The scopa of $M$. (Thyreotremma) sp. females (body length 11.14 $\mathrm{mm}$ ) are inserted on the basitarsus and are of two types: 1-unbranched, stiff, long and sparse (these were observed with L. elegans pollen attached); 2-short, slender, flexible bristles with many branches. 


\section{Behavior}

Females of T. anthracina, Rhophitulus sp., and Pseudagapostemon spp. visited flowers early in the morning, in synchrony with anther opening. Anthers which were encountered still closed were opened using their mandibles. Pollen was then removed using the front and middle legs and subsequently transferred to the scopa.

Females of $T$. anthracina rub their abdomen against the anthers, loading pollen directly into the scopa. While moving about on the flower, they would frequently come in contact with the stigma and deposit pollen upon it.

Females of Rhophitulus sp. and Pseudagapostemon spp. showed similar behavior. They would collect pollen with their front legs and transfer it to the scopa on their hind legs, occasionally coming into contact with the stigma.

Both females and males of $T$. anthracina inserted their tongues into one of the four floral nectaries in order to extract nectar. Then, in order to reach the next nectary, the bees would hold onto the anthers or the stigma with their hind legs while moving on the flowers. During these movements, pollen grains could be deposited on the stigma.

Rhophitulus sp. and Pseudagapostemon spp. insert their tongues into the nectary while moving around the base of the stamen or, less frequently, while holding onto the anthers with their hind legs. Due to the small size of these bees, they would only occasionally come into contact with the stigma. Other less frequent visitant bees, such as Augochlora amphitrite (Schrottky, 1909) (Halictidae), also collected nectar in this manner, although they don't seem to have an important role in pollination.

Males of T. anthracina, Rhophitulus sp. and Pseudagapostemon spp. were seen visiting $L$. elegans flowers later in the day than the females. They would patrol the flowers trying to mate with the females, although most attempts were unsuccessful.

Bees with a body length greater than $8 \mathrm{~mm}$, such as A mellifera $(10.14 \mathrm{~mm})$, Melissoptila sp. $(8.32 \mathrm{~mm})$, Melissoptila (Thyreotremma) sp. $(11.14 \mathrm{~mm})$, as well as other less frequent visitors such as Ptilothrix relata $(9 \mathrm{~mm})$, collected nectar in a manner similar to $T$. anthracina, effectively transferring pollen to the stigma of L. elegans flowers.

\section{DISCUSSION}

Flowers in populations of L. elegans examined in Aluminio and Campos do Jordão were self-incompatible. VIEIRA \& SHEPHERD (1998) had observed a similar self-incompatibility, although GIMENES (1997) reported self-compatibility among populations of $L$. elegans in Ribeirão Preto, São Paulo. According to RAMAMOORTHY (1979), self-compatibility is seen in some species of Ludwigia, which is in the section Myrtocarpus, where L. elegans is also placed. Additionally, RAVEN (1979) has shown that populations of the same species that are located in different areas may show differences in their reproductive biology. RAMAMOORTHY \& ZARDINI (1987) supported this finding with their observations of $L$. peruviana. 
A greater number of different bee species visited flowers of $L$. elegans at the Aluminio site than at Campos do Jordão. Previous studies had also demonstrated a greater number of bee species visiting $L$. elegans flowers at Ribeirão Preto than were seen at Campos do Jordão (GIMENES 1997). The lesser visitation observed at Campos do Jordão is probably the result of climatic differences derived from differences in altitude (both Aluminio and Ribeirão Preto experience higher average temperatures than does Campos do Jordão). DYLEWSKA (1991), observing bees at different altitudes in the Tatra region of Carpatos-Poland, found out larger numbers of bee species at lower altitudes. Likewise, SILVEIRA \& CURE (1993), observed differences in the composition of bee species at different altitudes in Brazil, which they also attributed to climatic differences.

Tetraglossula anthracina was considered a specialized visitor and was probably the most effective pollinator of $L$. elegans flowers at both the Aluminio and the Campos do Jordão sites. This bee species had a high visitation frequency and showed effective morphological and behavioral adaptations for pollen collection (for example, fast abdominal movements during collection) as well as for nectar harvesting. The bee's size also facilitated the transfer of pollen grains to the stigma. Additionally, males of this species establish breeding territories on the flowers of L. elegans that they inspect and defend. Similar behavior was also observed with $T$. bigamica at Ribeirão Preto (GIMENES 1997).

Rhophitulus sp. was also considered a specialized visitor of L. elegans flowers at both Aluminio and Campos do Jordão. Pseudagapostemon spp. was another a specialized visitor, but only at the Aluminio site. These two species are considered only casual pollinators, however, for their small size permits only infrequent contact with the floral stigma. GIMENES (1997) observed the same relationships between Pseudagapostemon brasiliensis and L. elegans flowers in Ribeirão Preto. SAZIMA \& SANTOS (1982) observed Pseudagapostemon sp. visiting flowers of Ludwigia sericea in Campinas, São Paulo State. Although a very frequent visitor, this bee species rarely acted as a pollinator and was thus considered a pollen thief.

Additionally, a circadian rhythm of pollen and nectar collection was observed in T. anthracina and Rhophitulus sp. at the Aluminio and Campos do Jordão sites (GIMENES et al. 1996) and were influenced by the light/dark and temperature cycles in both areas. Likewise, $T$. bigamica and $P$. brasiliensis were synchronized to the schedule of opening of L. elegans flowers at Ribeirão Preto (GIMENES et al. 1993).

Apis mellifera was a very frequent visitor to flowers of $L$. elegans at Aluminio, where it principally collected nectar. Although a generalized visitor, $A$. mellifera was considered an efficient pollinator because its size and behavior facilitate contact with floral reproductive structures during nectar collection. GIMENES (1997) observed similar relationships between A. mellifera and L. elegans flowers at Ribeirão Preto.

Bees specialized for pollen collection on Ludwigia flowers generally possess stiff and sparse bristles, which are simple or only slightly ramified. Additionally, their effectiveness at pollination is associated with other factors, such as: a high 
visitation frequency at the flowers, techniques of pollen collection (fast movements of the abdomen), techniques of nectar harvesting (grasping the anthers or the stigma with the posterior legs), and body size, which allows contact between these bees and the reproductive organs of the flower. These specific interactions between $L$. elegans flowers and specialized bees are maintained even in areas of different altitudes and under different climatic conditions.

\begin{abstract}
ACKNOWLEDGEMENTS. The author wish to thank M.A.C. Lopes for his help during the field observations and for preparing the figures, M.D. Marques for his collaboration, F. Zanella for critical reading the manuscript, as well as J.S. Moure, L. Ruz, G.A.R. Melo and D.A. Yanega for the identifications of the bees. To the administrator of Parque Estadual de Campos do Jordão and of the Fazenda Gir for the support during the field observation. Financial support received from CAPES and CNPq was greatly appreciated.
\end{abstract}

\title{
REFERENCES
}

Brack, P. 1985. Levantamento florístico do Parque Estadual do Turvo, Tenente Portela, Rio Grande do Sul, Brasil. Roesstéria, Porto Alegre, 7 (1): 23-42.

CRUden, R.W. 1981. Pollen-ovule ratio,pollen size and the ratio of stigmatic area to the pollen-bearing area of the pollinator:an hypothesis. Evolution 35 (5): 964-974.

DylewSKa, M. 1991. Apoidea of the Tatra Mountains and the adjacent area. Part I. Colletidae, Andrenidae, Halictidae, Melittidae, Megachilidae, and Anthophoridae. Acta zool. Cracov. 34 (1): 189-265.

Gimenes, M. 1991. Some morphological adaptations in bees (Hymenoptera, Apoidea) for collecting pollen from Ludwigia elegans (Onagraceae). Revta bras. Ent. 35 (2): 414-422.

1997. Pollinating bees and other visitors of Ludwigia elegans (Onagraceae) flowers at a tropical site in Brazil. Stud. Neotrop. Fauna Envir. 32 (2): 81-88.

Gimenes, M.; A.A. BENEdito-Silva \& M.D. MARQues. 1993. Chronobiologic aspects of a coadaptive process: The interaction of Ludwigia elegans flowers and its more frequent bee visitors. Chronobiol. Int. 10 (1): 20-30.

1996. Circadian rhythms of pollen and nectar collection by bees on the flowers of Ludwigia elegans (Onagraceae). Biol. Rhythm Res. 27 (3): 281-290.

HESSE, M. 1984. An exine architeture model for viscin threads. Grana, Stockholm, 23: 69-75.

HASSE, R. 1990. Plant communities of a savanna in northern Bolivia: II. Palm swamps, dry grassland, and shrubland. Phytocoenologia 18 (2-3): 343-370.

JacobS, S.W.L.; F. PerRetT; G.R. SAINTY; K.H. Browmer \& B.J. Jacobs. 1994. Ludwigia peruviana (Onagraceae) in the botany wetlands near Sydney, Australia. Aust. Jour. Mar. Freshwater Res. 45: $1481-1490$.

MacSwain, J.W.; P.H. RAVEN \& R.W. ThorP. 1973. Comparative behavior of bees and Onagraceae. IV. Clarkia bees of the Western United States. Univ. Calif. Publ. Entomol. 70: 1-80.

Martins, R.P. \& Y. Antonini. 1994. The biology of Diadasina distincta (Holmberg, 1903) (Hymenoptera: Anthophoridae). Proc. Ent. Soc. Wash. 96 (3): 553-560.

RAMAMOORTHY, T.P. 1979. A sectional revision of Ludwigia sect. Myrtocarpus s.lat. (Onagraceae). Ann. Missouri Bot. Gard. 66: 893-896.

Ramamoorthy, T.P. \& E.M. Zardini. 1987. The systematics and evolution of Ludwigia sect. Myrtocarpus sensu lato (Onagraceae). Monographs in Systematic Botany from Missouri Botanical Garden, vol. 19, 120p.

RAVEN, P.H. 1979. A survey of reproductive biology in Onagraceae. N.Z. Jour. Bot. Wellington 17: 575-593.

Revta bras. Zool. 19 (3): $681-689,2002$ 
RoberTS, R. \& S.R. VALLESPIR. 1978. Specialization of hairs bearing pollen and oil on the legs of bees (Apoidea:Hymenoptera). Ann. Ent. Soc. Amer. 71: 619-627.

Sazima, M. \& J.U.M. Dos SAntos. 1982. Biologia floral e insetos visitantes de Ludwigia sericea (Onagraceae). Bol. Mus. Paraense Emílio Goeldi, Sér. Botânica, Belém, 54: 1-12.

Seibert, P. 1975. Plano de manejo do Parque Estadual de Campos do Jordão. Bolm. téc. Inst. Florestal, São Paulo, 19: 1-153.

Silveira, F.A. DA \& J.R. CURE. 1993. High-altitude bee fauna of Southeastern Brazil: Implications for Biogeographic patterns (Hymenoptera: Apoidea). Stud. Neotrop. Fauna Envir. 28 (1): 47-55.

VIEIRA, A.O.S. \& G.J. SHEPHERD. 1998. Breeding systems in Ludwigia (Onagraceae) in Southeast Brazil, p. 395-406. In: S.J. Owens \& P.J. Rudall (Ed.) Reproductive Biology. Kew, Royal Botanic Gardens, 491p.

Received in 13.VII.2001; accepted in 18.VII.2002. 